\title{
Correlates of Parental Support and Academic Achievement of Male and Female Secondary School Students
}

\author{
Mohammad Hasan ${ }^{1} *$
}

\section{ABSTRACT}

Exponential growth of academic competitiveness has brought out the dire needs of Parental support. School education cannot visualise the all objectives of education until it sought parental support. Thus, parental support has become the crux of modern school education. The present study aims to explore the relationship as well as difference between academic achievements of high and low parental support groups of male and female secondary school students. The study is hypothesised as there will be no relationship and difference between academic achievements of high and low parental support groups of male and female secondary school students. A sample size of 205 (Male \& Female) secondary school students was drawn from four secondary schools of Aligarh Muslim University, Aligarh (U.P.) India. Non-probability purposive sampling was employed to draw the required sample. Mean. SD, Pearson Correlation and t- test was calculated for the analysis of data. Findings revealed the positive significant relationship as well as no significant difference between academic achievements and parental support of secondary school students. Findings are interpreted in terms of educational implications and need for further research is also suggested.

Keywords: Parental Support; Academic Achievement; Gender; Secondary School Students

Education is the process of developing capacities and potentialities of individual so as to prepare that individual to be successful in specific society and culture. In Indian society, the basic criterion to measure a student's potentialities is the academic achievement. It holds a very important place in education and learning process. All parents want their child to be on the top ranking, that leads the child in the severe anxiety and strain towards examination. The need of high achievement puts pressure on the students, teachers and schools so much so the whole system in turn seems to be revolving around academic achievement of students. At this juncture, students have very dire need of parental support in the form of motivation, financial support, proper care and guidance at home etc. to cope up the stress and anxiety caused by high expectations to perform in various tests and examinations.

\footnotetext{
${ }^{1}$ Research Scholar, Department of Education, Aligarh Muslim University, Aligarh (U.P.), India

*Responding Author

(C) 2016 I M Hasan; licensee IJIP. This is an Open Access Research distributed under the terms of the Creative Commons Attribution License (http://creativecommons.org/licenses/by/2.0), which permits unrestricted use, distribution, and reproduction in any Medium, provided the original work is properly cited.
} 


\section{Correlates of Parental Support and Academic Achievement of Male and Female Secondary School Students}

\section{Parental Support}

Parental support refers here to the help provided by the parents to their children in relation to their studies. Parents are recognised as the first and most important teacher in the students' life. Parent support is one of the most important contributions of parents that can make positive impression in the process of adolescents' development. “Adolescents need their parents both for guidance and support during this crucial point in their life” (Badony, 2000). It is a common assumption in the literature that greater the parents support, greater the social competence (selfesteem, moral behaviour, academic achievement and vocational achievement). Parents assist their children's development by providing opportunities to them to explore, express themselves and exercise their willing and imagination.

Way and Raossman (1997) emphasised that "Interactions between parent and adolescents include positive behaviour such as interests, support, communication openly and parent child connectedness, help adolescents learn to be autonomous and successful in shaping their own lives”.

\section{Academic Achievement}

Academic achievement concerns with achievement of students. It plays key role in declaring students' success and unsuccessfulness. It also helps in selecting students for different courses and recruiting students for various jobs. In general parlance, academic achievement is the level of learning outcome in a particular area of subject in relation to knowledge, understanding, skill and application which are usually evaluated by concerned teachers in the form of test scores and examination. C.V. Good (1973), defined academic achievement as, "knowledge attained or skills developed in the school subjects, usually designated by test scores or by marks assigned by teachers or both.” It is also considered as a key instrument through which students learns about their talents and competencies which are recognised as an essential part of developing career aspirations.

Academic achievement of students depends upon several factors. Parental support is one of them. The present study is an attempt to reveal whether performance of students reporting high parental support is different from those reporting low parental support, and also to reveal that, is there any difference in the academic achievement of students on the basis of students' parents' service?. In the present study academic achievement is taken as the performance of students after a course and is calculated in terms of marks obtained by the teachers.

\section{REVIEW OF LITERATURE}

Nam \& Park (2014) found significant difference in ethnicities, the children's school levels and the fathers' educational level, learning at home and type of parental involvement. Kikas, Tulviste \& Peets (2013) found that mothers are seemed to be more involved in their children education than father and also reported that family socialization values had negative impact on parental 


\section{Correlates of Parental Support and Academic Achievement of Male and Female Secondary School Students}

involvement. Thompson, B. \& Mazer, J.P. (2012) reported the developmental procedure of tool concerning to the efficacy of parental support. Schary, Cardinal \& Lepronzi, (2012) found a positive association between child's active play behaviour and parental support . You \& Nguyen (2011) reported that parental involvement dimensions positively influenced academic achievement. Hornby \& Lafaelee (2011) proposed a model to understanding the barriers of parental involvement concerning to the professional achievement. Lau et al (2011) found that parental involvement is highly correlated with overall readiness for the school. Stringer \& Kerpelam (2010) reported that parental support for career and number of jobs held predicted career identity evaluation. Starkey \& Klein (2010) reported that parental support to the children through the intervention was effective in enhancing the development of children's mathematical knowledge. Jones, C (2009) revealed that parents gave impotence to the MFls so they could help their child in studying MFl. However, gender differences were observed on the attitudes towards MFL. Barges \& Kristjansson (2009) revealed that parental monitoring has similar effect on academic achievement among boys and girls. Bokszczanin (2008) highlighted that lower parental support is found to be associated with greater perceived conflict within the family and greater parental over protectiveness. Loges (2003) reported that communication is an importance tool in academic progress as well as developing understanding and agreements among parents, teachers and community members. However, after a very comprehensive review of literature, researcher could not found any such a study that was related to the present research problems. Thus, the present research problem; Correlates of Parental Support and Academic Achievement of Male and Female Secondary School Students, would be helpful in filling up the research gaps of concern problems.

\section{Variables of the Study}

1. Dependent Variable: academic achievement

2. Independent Variable: Parental Support ( Male \&Female)

\section{OBJECTIVES OF THE STUDY}

1. To find out the relationship between parental support and academic achievements of secondary school students.

2. To examine the effect of high and low parental support on the academic achievements of secondary school students.

3. To investigate the impact of high and low parental support on the academic achievements of male secondary school students.

4. To explore the effect of high and low parental support on the academic achievements of female secondary school students

5. To discover the effect of high parental support on the academic achievements male and female secondary school students.

6. To investigate the impact of the low parental support on the academic achievements of male and female secondary school students. 


\section{Correlates of Parental Support and Academic Achievement of Male and Female Secondary School Students}

\section{Hypotheses}

1. There will be no significant relationship between parental support and academic achievements of secondary school students.

2. There will be no significant difference between academic achievements of high and low parental support groups of secondary school students.

3. There will be no significant difference between the academic achievements of high and low parental support of male secondary school students.

4. There will be no significant difference between the academic achievements of high and low parental support of female secondary school students.

5. There will be no significant difference between the academic achievements and high parental support groups of male and female secondary school students.

6. There will be no significant difference between the academic achievements and low parental support groups of male and female secondary school students.

\section{METHODS AND MATERIALS}

Design: Present research study confirms the criteria of descriptive research. Hence, it is a descriptive research and valid data were collected through standardised research tool. Thus, a suitable survey design was put in to operation for the present research study.

Population: Secondary school students of Aligarh District are constituted the population of the study.

Sample: In the present study, a sample size of 205(Male \& Female) students of secondary school students was considered ideal for carrying the study. For the collection of ideal sample, purposive sampling technique was applied on the population.

Research Tool Used: A standardised Parental Support Scale (P.S.S.), developed by Nadawana, S \& Asawa, N. (2011), with a reliability index of 0.74, was put in used for the present research study. The used scale consists of three dimensions; namely Interest, behaviour and resource provision. It has 37 statements, 28 of these are favourable stated while remaining 9 are negatively stated. All the statements are set against a 3 point scale of Always, Sometimes, and Never. Scoring pattern is arranged like ' 3 , 2, and 1 for the favourably stated statements and 1 , 2, and 3 for non- favourably stated statements.

The achieved marks of students from previous class were confirmed as an index of Secondary School Students' academic achievement. Data, based on personal profile were also collected by using researcher's developed personal data sheet.

Data Collection: The Researcher personally made certain successful attempts for visiting the four selected secondary schools of Aligarh Muslim University, Aligarh (U.P.) India. A 


\section{Correlates of Parental Support and Academic Achievement of Male and Female Secondary School Students}

standardised research tool of Parental Support along with the personal data sheet was administered on a total sample size of 205 (Male \& Female) Secondary School Students. At a justifiable level of freedom, pertaining to ask meaning of difficult words or sentences was extended to the students for making their impressions on the each printed items.

\section{Data Analysis and Interpretation}

Table: 1. Showing relationship between the parental support and academic achievements of secondary school students

\begin{tabular}{|l|l|l|c|}
\hline Basis & No. & Df & $\begin{array}{l}\text { Correlation (r) } \\
\text { (Pearson Product) }\end{array}$ \\
\hline Parental Support & 205 & 203 & $0.307 *$ \\
\hline Academic achievements & 205 & & \\
\hline
\end{tabular}

*At 0.05 level of significance

A glimpse of above drawn table shows a correlation (r) value as 0.307 and that is statistically significant at the significance level of 0.05 . Hence the null hypothesis is rejected .Thus, a significant positive correlation was found between the parental support and academic achievement of secondary school students. However, the result signifies that if the parental support of students will increase, likewise, the academic achievement of theirs will also increase. The analysed dimensions of both variables have positive linear relationship.

Table: 2. Showing difference between the academic achievements of high and low parental support groups of secondary school students

\begin{tabular}{|c|c|c|c|c|c|}
\hline Basis & No. & Mean & SD & Df & t- value \\
\hline $\begin{array}{l}\text { Academic achievements of high } \\
\text { parental support group of students }\end{array}$ & 113 & 412.85 & 79.68 & \multirow{2}{*}{203} & \multirow{2}{*}{0.64} \\
\hline $\begin{array}{l}\text { Academic achievements of low } \\
\text { parental support group of students }\end{array}$ & 92 & 345.51 & 67.81 & & \\
\hline
\end{tabular}

At 0.05 significant level

A close view of table 2 reflects the t- value as 0.64 and that is not statistically significant at the significance level of 0.05 . Hence, the null hypothesis is accepted. It means, no significant difference was found between the academic achievements of high and low parental support groups of secondary school students. Thus, both the low and high parental support groups of secondary school students confirmed the same level of academic achievement. 
Table: 3. Showing difference between the academic achievements of high and low parental support of male secondary school students

\begin{tabular}{|l|l|l|l|l|l|}
\hline Basis & No. & Mean & SD & Df & t- value \\
\hline $\begin{array}{l}\text { Academic achievements of high } \\
\text { parental support group of male } \\
\text { students }\end{array}$ & 59 & 415.55 & 81.60 & 106 & 0.77 \\
\hline $\begin{array}{l}\text { Academic achievements of low } \\
\text { parental support group of male } \\
\text { students }\end{array}$ & 49 & 336.61 & 61.21 & & \\
\hline
\end{tabular}

At 0.05 significant level

A close examination of table 3 gives the t- value as 0.77 and which is not confirmed as statistically significant at mentioned 0.05 significance level. Thus, the accrued t- value confirmed no significant difference between the high and low parental supports of male secondary school students. Both the statistically analysed variables' dimensions reported similar level of academic achievements.

Table: 4. Showing difference between the academic achievements of high and low parental support of female secondary school students

\begin{tabular}{|l|l|l|l|l|l|}
\hline Basis & No. & Mean & SD & Df & t- value \\
\hline $\begin{array}{l}\text { Academic achievements of high } \\
\text { parental support group of female } \\
\text { students }\end{array}$ & 54 & 409.90 & 77.06 & 95 & 0.50 \\
\hline $\begin{array}{l}\text { Academic achievements of low } \\
\text { parental support group of female } \\
\text { students }\end{array}$ & 43 & 355.65 & 74.88 & & \\
\hline
\end{tabular}

At 0.05 significant level

A close panoramic view of table 4 shows the t- value as 0.50 and that is not statistically significant at the significance level of 0.05 . Hence, the null hypothesis is again accepted. Therefore, no significant difference was observed between the academic achievements of high and low parental support groups of female students. Thus, the academic achievements of high and low parental support groups of female students manifested similar academic performance.

Table: 5. Showing difference between the academic achievements of high parental support of male and female secondary school students

\begin{tabular}{|l|l|l|l|l|l|}
\hline Basis & No. & Mean & SD & Df & t- value \\
\hline $\begin{array}{l}\text { Academic achievements of high } \\
\text { parental support group of male } \\
\text { students }\end{array}$ & 59 & 412.85 & 79.68 & 111 & 0.05 \\
\hline $\begin{array}{l}\text { Academic achievements of high } \\
\text { parental support group of female } \\
\text { students }\end{array}$ & 54 & 345.51 & 67.81 & & \\
\hline
\end{tabular}

At 0.05 significant level 


\section{Correlates of Parental Support and Academic Achievement of Male and Female Secondary School Students}

At a glance, table 5 reflects the t-vale as 0.05 and that is not established as statistically significant at the 0.05 level of significance. Hence, once again the null hypothesis is accepted. Therefore, finding suggested no significant difference between the academic achievements of high parental support of male and female secondary school students.

Table: 6. Showing difference between the academic achievements of low parental support of male and female secondary school students

\begin{tabular}{|l|l|l|l|l|l|l|}
\hline Basis & No. & Mean & SD & Df & t- value \\
\hline $\begin{array}{l}\text { Academic achievements of low } \\
\text { parental support group of male } \\
\text { students }\end{array}$ & 49 & 336.61 & 61.21 & 90 & 0.19 \\
\hline $\begin{array}{l}\text { Academic achievements of low } \\
\text { parental support group of female } \\
\text { students }\end{array}$ & 43 & 355.65 & 74.88 & & \\
\hline
\end{tabular}

At 0.05 significant level

As the above mentioned table reveals the $t$ - value is 0.19 between the academic achievements of low parental support of male and female secondary school students. This observed t- value is not statistically significant at the significance level of 0.05 . Therefore, null hypothesis is accepted and it signifies a similar academic achievements level between the low parental support of male and female secondary school students.

\section{FINDINGS OF THE STUDY}

1. Significant positive correlation was found between the academic achievements and parental support of secondary school students.

2. No significance difference was found between the academic achievements of high and low parental support groups of secondary school students.

3. No significant difference was found between the academic achievements of high and low parental support of male secondary school students.

4. No significant difference was found between the academic achievements of high and low parental support groups of female secondary school students.

5. No significant difference was found between the academic achievements of high parental support groups of male and female secondary school students.

6. No significant difference was found between the academic achievements of low parental support groups of male and female secondary school students

\section{CONCLUSION}

Increasing work load at schools has called the maximum level of parental support and caring to the students. Present era has now been confirmed as the era of knowledge. Knowledge at every seats of learning is getting diversified with special concern to the employment. Thus, on a 


\section{Correlates of Parental Support and Academic Achievement of Male and Female Secondary School Students}

mandatorily ground, proper caring of students should become the basic preference of parents. Parents are supposed to be a good friend as well as counsellor to their children in regards to students' academic process. Thus, on a larger ground, academic performance of students depends not only on the learned teachers but also on a highly responsible parent too. In the present study, a positive correlation was found between the academic achievements and parental support of secondary school students. Finding suggests that if the parental support of students will be increased in a proper way then their academic performance will also be improved.

\section{EDUCATIONAL IMPLICATIONS}

Every sorts of knowledge barring a quality of utility with the hidden perspectives of social welfare. All previous and present researches are considered as a meaning full agent in the addition of existing knowledge. No research could be confirmed as value laden unless it has the answers of existing problems. Thus, research study should have its implicational aspects. Present research has its implication regarding to the importance of parental support in the betterment of the academic performance of the students. Existing school system has indicated to the educational stake holders to seek proper cooperation and support of parents to enhance the learning capability of students as well as to get over come the effect of social evils. In the light of findings, socialisation process and moral development of students at school and home could be revamped and improvised.

\section{SUGGESTIONS FOR STUDY}

No research could be the last bullet to shoot the concern problem. Every research has its limitations to answer the pertinent problem and also leave behind an accepted research gaps and questions for further studies. Likewise, present research has also left certain questions to be answered and that could only be realised when the similar study would be conducted on larger sample size. Very similar study could also be surfaced by incorporating the various issues regarding the parental support of students at different levels. A more worthy generalisation can be possible on the selected variables by comparing the public and private schools students.

\section{REFERENCES}

Bages, L.E., \& Loges, W.E. (2003). Parent, Student and Teacher Perceptions of Parental Involvement. Journal of Applied Communication Research, Vol. 31 (2), pp.140-163. http://dx.doi.org/10.1080/0090988032000064597

Bokszczanin, A. (2008). Parental Support, Family Conflict, and over Protectiveness: Predicting PTSD Symptom Level of Adolescents 28 Month after a Natural Disaster. Anxiety, Stress, and Coping: An International Journal, Vol. 21(4), pp.325-335. Retrieved fromhttp://dx.doi.org/10.1080/10615800801950584.

Good, C.V. (1973). Dictionary of education, New York, McGraw Hill Book Company, p.7.

Hoing, A.S. \& Zdunowski-Sijblom, N. (2014). Bullied Children: Parent and School Supports. Early Child Development and Care, Vol. 184(9-10). pp. 1378-1402. Available at http://dx.doi.org/10.1080/03004430.2014.901010. 


\section{Correlates of Parental Support and Academic Achievement of Male and Female Secondary School Students}

Hrnyby, G \& Laelee, R. (2011). Barriers to Parental Involvement in education: An explanatory Model. Educational Review, Vol. 63 (1), pp. 37-52. Retrieved from http://dx.doi. Org/10.1080/00131911.2010.488049.

Jones, C. (2009). Parental Support and the Attitudes of Boys and Girls to Mother Foreign Languages. The Language Learning Journal, Vol. 37(1), pp. 85-97. Available at http://dx.doi.org/10.1080/09571730902717349

Kikas, E., Tulviste, T \& Peets, K. (2013). Socialization and Parenting Practices as Predictors of Parental Involvement in their Children's Education Process. Early Education and Development, Vol.25 (1), pp.1-18.Retrieved from http:// dx.doi.org/10.1080/ 10409289.2013.780503.

Kristjansson, A.L., Sigfusdottir, I. (2009). The role of parental support, parental Monitoring and Time spent with parents in Adolescent Academic Achievement in Iceland: A Structural Model of Gender Differences. Scandinavian Journal of Educational Research, Vol.35 (5), pp. 481496.

La Forett, D.R., Mendez, J.L, (2010). Parental Involvement, Parental Depression, and Program Satisfaction among Low and income Parents Participating in a Two Generation Early Child Hood Education Programme. Early Education and Development, Vol.21 (4), pp. 517-535. Available at http://dx.doi.org/10.1080/10409280902927767.

Lau, E.Y.H., Li, H. \& Rao, N. (2011). Parental Involvement and Children's Readiness for the School in China. Educational Research, Vol. 53(1), pp. 95-113. Retrieved fromhttp://dx.doi.org/10.1080/00131881.2011.552243.

Nam, B.H. \& Park, D.B. (2014). Parent Involvement and Perceptions of Recent Immigrant Parents in a Sub-Urban School District, Minnesota. Educational Studies, Vol. 40 (30), pp. 310-329. Available at http://dx.org./1080/030055698.2014.898576.

Nandwana, S \& Asawa, N. (2011).Manual for Parental Support Scale. National Psychological Corporation, Agra (U.P.) India- 282004.

Schary, D.P., Cardinal, B.J. \& Lepronzi, D.P. (2012). Parental Support Exceeds Parenting Style for Promoting Active Play in Preschool Children, Early Child Development and Care, Voll.182 (8), pp. 1057-1069.Available at http://dx.doi.org/10.1080/03004430.2012.685622.

Sharpe, P. (2006). Teaching and Learning at Home: Features of Parental Support for the bilingual Competence of Pre-School. Early Child Development and Care, Vol.130 (1), pp. 75-83. Available at http:// dx.doi.org/10.1080/0300443971300108.

Starkey, P \& Klein, A. (2010). Fostering Parental Support for Children's Mathematical Development: An Introduction to Head Start Families. Early Education and Development, Vol. 11 (5), pp.659-680. http://dx.doi.org/10.1207/s15566935eed1105_7.

Stinger, K. J. \& Kerpelam, J.L. (2010). Career Identity Development in College Students: Decision Making, Parental Support, and Work Experience. Identity: An International Journal of Theory and Research, Vol.10 (3), pp. 180-20. Available at http:// dx.doi.org/10.1080/152834888.2010.496102. 


\section{Correlates of Parental Support and Academic Achievement of Male and Female \\ Secondary School Students}

Thompson, B. \& Mazer, J.P. (2012). Development of the Parental Academic Support Scale: Frequency, Importance, and Modes of Communication. Communication Education, Vol. 61(20), pp. 131-160. Available at http://dx.doi.org/10.1080/03634523.2012.657207.

Vandermass-Peeler, M., Boomgarden, E., Finn, L., \& Pittard, C. (2012). Parental Support of Numeracy during a Cooking Activity with Four-Year- Olds. International Journal of Early Year Education, Vol, 20(1), pp.78-93. Available at http://dx.doi.org/10.1080/09669760.2012.663237.

Veland, J., Brue, E., Idsoe, T. (2014). Perceived Socio-economic Status and Social Inclusion in School: Parental Monitoring and Support as Mediators. Educational and Behavioural Difficulties, pp. 1-17. Available at htpp://dx.doi.org/10.1080/13632752.2014.931018.

Way,W.L. \& Rossmann, M.M. (1997). Learning to work: How parents nurture the transition from school to work. Family matters.... in school to work transition.

You, S \& Nguyen, J. (2011). Parents' Involvement in Adolescent's Schooling: A Multidimensional Conceptualization and Meditational Model. Educational Psychology: An International Journal of Experimental Psychology, Vol. 35, (5), pp. 547-558. Retrieved from http://dx.doi.org/10.1080/01443410.2011.577734. 